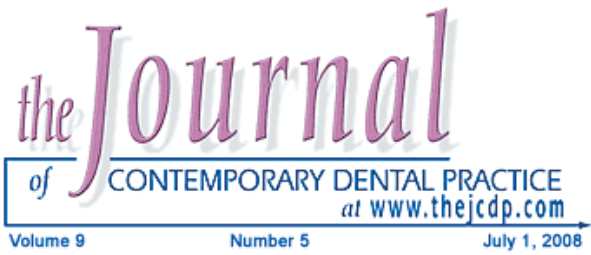

\title{
Survey of Talon Cusps in the Permanent Dentition of a Turkish Population
}

\section{Kaan Gunduz, DDS; Peruze Celenk, DDS, PhD}

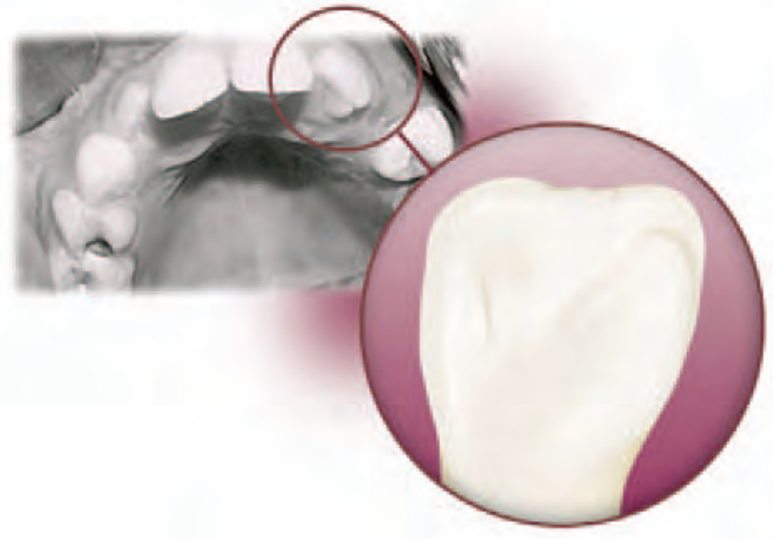

\section{Abstract}

Aim: Talon cusp is the name given to the accessory tubercles located on the lingual faces of anterior teeth. The occurrence of talon cusps has been reported among Europeans and Asians. However, there are few reports of this anomaly in Caucasians as well as a paucity of literature on its characteristics. Today there are seven million Turkish citizens of Caucasian origin that have settled in the Marmara, Central-Anatolia, East-Anatolia, and Black Sea regions of Turkey. The aim of this study is to present 27 Caucasian cases with 33 taloned teeth. This study is the first that was undertaken to investigate the characteristics of talon cusps in a group of Turkish people.

Methods and Materials: A survey of 27 patients examined in the Department of Oral Diagnosis and Radiology at Ondokuz Mayıs University in Samsun, Turkey between January, 2003 and June, 2006 was conducted. Their ages ranged from seven to 33 years. A total of 33 talon cusps were diagnosed in the 27 patients. The patients' records and radiographs were evaluated and the following variables were studied: age, sex distribution, affected tooth, type of talon cusp, radiographic evidence of pulp extension, and associated dental anomalies and complications.

Results: There were 13 male and 14 female patients with a gender ratio of approximately $1: 1$. Ten of 33 talon cusps $(30 \%)$ were seen in maxillary right central incisors while four cases $(12 \%)$ were in maxillary left central incisors and nine cases $(27 \%)$ were in maxillary right lateral incisors. Eight cases $(24 \%)$ were seen in maxillary left lateral incisors, one case (3\%) was in a mandibular right central incisor, and one case (3\%) was

(c) Seer Publishing 
in a mandibular left canine. Fifteen (15) of the 33 talon cusps were Type 1 talons (45\%), while eight cases (24\%) were Type 2 talons and ten cases (30\%) were Type 3 talons. Twelve of the 33 talon cusps $(36 \%)$ showed radiographic evidence of pulpal extension into the tubercule on periapical radiographs. One patient had gemination $(3 \%)$ on the maxillary permanent incisors and two patients had mesiodens $(6 \%)$ in the maxillary anterior region.

Conclusion: The talon cusp remains as one of the more uncommon dental anomalies worldwide and in Turkey and presents with different clinical features.

Clinical Significance: The talon cusp may be more likely to be associated with other odontogenic anomalies and some systemic conditions; early recognition of this anomaly is essential to provide proper treatment.

Keywords: Talon cusp, dental anomaly, accessory tubercles

Citation: Gündüz K, Çelenk P. Survey of Talon Cusps in the Permanent Dentition of a Turkish Population. J Contemp Dent Pract 2008 July; (9)5:084-091.

\section{Introduction}

Talon cusp is the name given to the accessory tubercles located on the lingual surfaces of anterior teeth. ${ }^{1}$ Mader $^{2}$ proposed the term be reserved for "anomalous cusps of succedaneous incisor teeth." Shafer et al. ${ }^{3}$ describes a talon cusp as an uncommon anomalous structure composed of normal enamel and dentin which projects from the cingulum area of maxillary or mandibular permanent incisors in a fashion resembling an eagle's talon. A more critical definition was suggested by Davies and Brook. ${ }^{4}$ They defined talon cusp as an additional cusp that prominently projects from the lingual surface of primary or permanent anterior teeth, is morphologically well delineated, and extends at least half the distance from the cementoenamel junction to the incisal edge.

Although the exact etiology of the anomaly has not been established, it is suggested the talon cusp has a multifactorial etiology combining both genetics and environmental factors. ${ }^{5,6} \mathrm{~A}$ talon cusp may present clinically as an isolated entity or in association with other dental anomalies, and it has been associated with some systemic conditions such as Mohr syndrome (orofacialdigital II), ${ }^{10}$ Sturge-Weber syndrome (encephalotrigeminal angiomatosis), ${ }^{18}$ Rubinstein-Taybi syndrome, ${ }^{11}$ incontinentia pigmenti achromians, ${ }^{19}$ and Ellis-van Creveld syndrome. ${ }^{20}$

The talon cusp may present problems during diagnosis and management. A talon cusp on an unerupted tooth may be confused radiographically with a supernumerary tooth, compound odontoma, or a dens in dente. ${ }^{1-2,6-8}$ Depending on the size and configuration of the cusp and the arch in which it occurs, a talon cusp may be esthetically displeasing and irritating to the tongue. Histological studies have shown this cusp to consist of enamel and dentin with or without a slender extension of the pulp from the pulp chamber. ${ }^{6,12}$ Radiographic examination may reveal the presence of this pulpal extension. ${ }^{5,6,12}$ There is a tendency for caries to occur in the developmental grooves where the cusp joins the lingual surface of the crown and, if neglected, pulpal necrosis may result. ${ }^{1-8}$ Occlusal interference is often a problem with talon cusps, particularly those occurring in the maxilla. ${ }^{1,6-8}$

A review of the literature revealed 34 articles on talon cusps were published in English language dental iournals. Of these, 23 articles were on

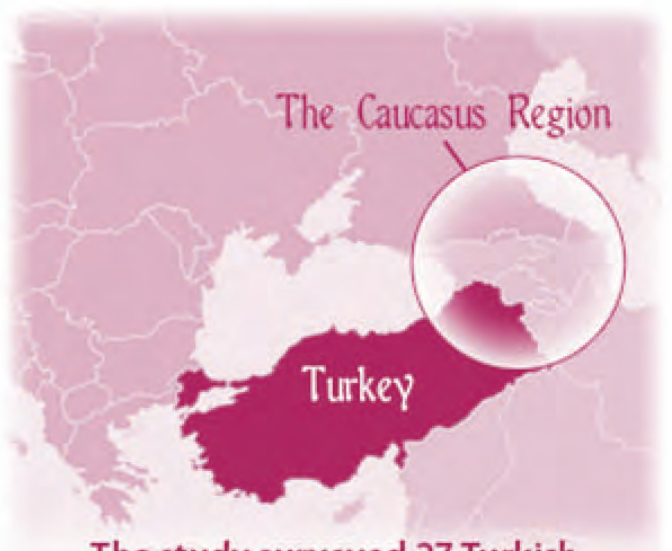

The study surveyed 27 Turkish patients of Caucasian origin. 
permanent teeth and described 72 patients with 96 affected (taloned) teeth. Almost $90 \%$ of the taloned teeth were found in the maxilla and distributed as follows: 54 (56.2\%) lateral incisors, 34 (35.4\%) central incisors, and eight (8.3\%) canines. The 11 reports of talon cusp in primary teeth involved 36 taloned teeth, in which nine cases had bilateral talon cusps. The occurrence of talon cusp is reported to be three times higher in the permanent dentition than in the primary dentition. However, in the primary dentition, the maxillary central incisors have been most frequently involved, followed by lateral incisors and canines. Males are more frequently affected than females. ${ }^{6,7}$

There are insufficient data regarding the prevalence of talon cusp. The prevalence is calculated between 1 to $2 \%$ in many Asian communites ${ }^{5}$ and between 3 to $4 \%$ in Eskimos and North American Indians. ${ }^{5,6}$ As reported in several studies, this anomaly occurs with a higher incidence in Mongoloid populations than in Caucasians and Negroes. ${ }^{5}$ However, the lack of precise criteria to classify an accessory cusp as a talon may contribute to the variations between different populations. Recently, a classification system for these anomalous cusps, based on their morphology and size, was proposed in the literature. ${ }^{6}$

The occurrence of talon cusps has been reported among Europeans and Asians. However, there are few reports of this anomaly in Caucasians as well as a paucity of literature on its characteristics. Today there are seven million Turkish citizens of Caucasian origin that have settled in the Marmara,
Central-Anatolia, East-Anatolia, and Black Sea regions of Turkey. The aim of this study is to present 27 Caucasian cases with 33 taloned teeth among them. This study is the first that was undertaken to investigate the characteristics of talon cusp in a group of Turkish people.

\section{Methods and Materials}

A survey of 27 patients who visited the Department of Oral Diagnosis and Radiology, Ondokuz Mayıs University in Samsun, Turkey, between January, 2003, and June, 2006 was conducted. These patients had adequate radiographic surveys (pantomographs and periapical radiographs) that showed good dental definiton. All incisors were examined for talon cusps. The definition of talon cusp, as suggested by Hattab et al., ${ }^{6}$ was used in assessing teeth (Table 1). The patients' records and radiographs were evaluated and the following variables were studied: age and gender distribution, affected tooth, radiographic evidence of pulp extension, associated dental anomalies and complications, and type of talon cusp.

\section{Results}

\section{Age and Gender Distribution}

Between January, 2003, and June, 2006, 33 talon cusps were diagnosed in 27 patients. The age range was seven to 33 years old. Approximately $93 \%$ of the patients had only one talon cusp, while in $7 \%$ of the cases two talon cusps were present. There were 13 male and 14 female patients with a gender ratio of approximately 1:1 (Table 2).

Table 1. Classification system of talon cusp.

\begin{tabular}{|l|l|}
\hline Type 1 Talon & $\begin{array}{l}\text { A morphologically well-delinated additional cusp that prominently projects from the } \\
\text { palatal surface of a primary or permanent anterior tooth and extends at least half the } \\
\text { distance from the cementoenamel junction to the incisal edge. }\end{array}$ \\
\hline Type 2 Semitalon & $\begin{array}{l}\text { An additional cusp of a millimeter or more but extending less than the distance from } \\
\text { the cementoenamel junction to the incisal edge. It may blend with the palatal } \\
\text { surface or stand away from the rest of the crown. }\end{array}$ \\
\hline Type 3 Trace Talon & $\begin{array}{l}\text { Enlarged or prominent cingula and their variations, i.e., conical, bifid, or tubercle- } \\
\text { like. Radiographically it may appear typically as V-shaped radiopaque structure, as } \\
\text { for true talon and semitalon, or tubercle-like, originating from the cervical third of the } \\
\text { root. }\end{array}$ \\
\hline
\end{tabular}


Table 2. Radiographic appearance and associated dental complications and anomalies observed in patients with talon cusp.

\begin{tabular}{|c|c|c|c|c|c|c|}
\hline Case & Age & Sex & $\begin{array}{l}\text { Affected } \\
\text { Tooth }\end{array}$ & $\begin{array}{c}\text { Type of } \\
\text { Talon Cusp }\end{array}$ & $\begin{array}{c}\text { Pulp } \\
\text { Extension } \\
\text { Into the Cusp }\end{array}$ & $\begin{array}{l}\text { Associated Dental } \\
\text { Anomalies \& } \\
\text { Complications }\end{array}$ \\
\hline 1 & 20 & Male & 31 & Semitalon & Absent & None \\
\hline 2 & 33 & Male & 12 & Talon & Present & Occlusal interference \\
\hline 3 & 20 & Male & 22 & Semitalon & Absent & None \\
\hline 4 & 10 & Female & 22 & Talon & Absent & None \\
\hline 5 & 22 & Female & 12 & Semitalon & Absent & Occlusal interference \\
\hline 6 & 21 & Male & 12,22 & Tracetalon & Absent & None \\
\hline 7 & 23 & Female & 11,12 & Tracetalon & Absent & None \\
\hline 8 & 18 & Male & 12 & Talon & Present & $\begin{array}{l}\text { Occlusal interference, } \\
\text { gemination on } 11 \text { and } \\
21\end{array}$ \\
\hline 9 & 23 & Male & 11 & Talon & Present & Deep grooves \\
\hline 10 & 24 & Male & 11 & Talon & Present & Occlusal interference \\
\hline 11 & 17 & Male & 21,22 & Talon & Present & Carious grooves \\
\hline 12 & 15 & Female & 11,12 & Tracetalon & Absent & None \\
\hline 13 & 12 & Female & 21 & Semitalon & Absent & Mesiodens \\
\hline 14 & 15 & Female & 22 & Talon & Present & Deep grooves, \\
\hline 15 & 7 & Female & 11 & Talon & Absent & None \\
\hline 16 & 13 & Male & 11,21 & Tracetalon & Absent & None \\
\hline 17 & 14 & Male & 22 & Semitalon & Absent & None \\
\hline 18 & 21 & Male & 43 & Talon & Present & None \\
\hline 19 & 16 & Female & 21,22 & Tracetalon & Absent & None \\
\hline 20 & 15 & Female & 11 & Talon & Present & Carious grooves \\
\hline 21 & 16 & Male & 12 & Talon & Present & Mesiodens \\
\hline
\end{tabular}


Table 2. (Continued.) Radiographic appearance and associated dental complications and anomalies observed in patients with talon cusp.

\begin{tabular}{|c|c|l|c|l|l|l|}
\hline 22 & 15 & Female & 22 & Talon & Absent & None \\
\hline 23 & 24 & Male & 22 & Talon & Present & Deep grooves \\
\hline 24 & 14 & Female & 11 & Semitalon & Absent & None \\
\hline 25 & 16 & Male & 12 & Semitalon & Absent & None \\
\hline 26 & 19 & Female & 11 & Semitalon & Absent & Carious grooves \\
\hline 27 & 20 & Female & 11 & Talon & Present & None \\
\hline
\end{tabular}

\section{Distribution of Teeth with Talon Cusps} In this study talon cusps were detected in the permanent maxillary and mandibular incisors. Ten of 33 talon cusps (30\%) were seen in maxillary right central incisors while four cases $(12 \%)$ were in maxillary left central incisors. Nine cases $(27 \%)$ were in maxillary right lateral incisors. Eight cases (24\%) were seen in maxillary left lateral incisors, one case $(3 \%)$ was in a mandibular right central incisor, and one case $(3 \%)$ was in a mandibular left canine. In most of the patients the talon cusp occurred unilaterally. Of the 27 subjects, only two (7\%) had a symmetrically bilateral occurrence (Table 2 ).

\section{Type of Talon Cusp}

In this study talon affected teeth were classified as suggested by Hattab et al. ${ }^{6}$ As shown in Table 2, 15 of 33 talon cusps were Type 1 talon (45\%), while eight cases (24\%) were Type 2 talon and ten cases (30\%) were Type 3 talon (Figures 1, 2, and 3 ).

\section{Radiographic Examination}

It is difficult to identify the pulpal configuration of a talon cusp on a radiograph because the cusp is superimposed over the affected tooth crown. It has been suggested large talon cusps, especially those separated or project away from the tooth crown, are more likely to contain pulp tissue. For this reason, only 12 out of the 33 talon cusps (36\%) showed radiographic evidence of pulpal extension into the tubercule on periapical radiographs (Table 2) (Figures 4, 5, and 6).

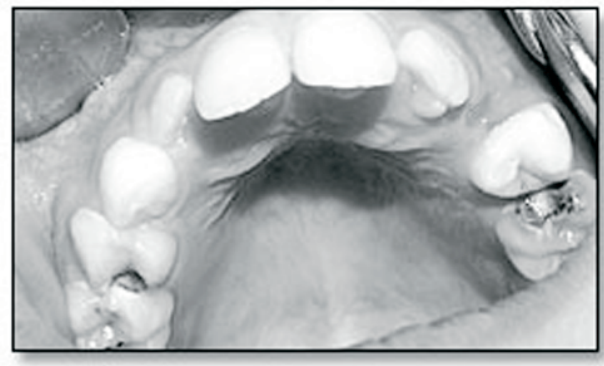

Figure 1. Intraoral view of a Type 1 talon cusp on a maxillary left lateral incisor.

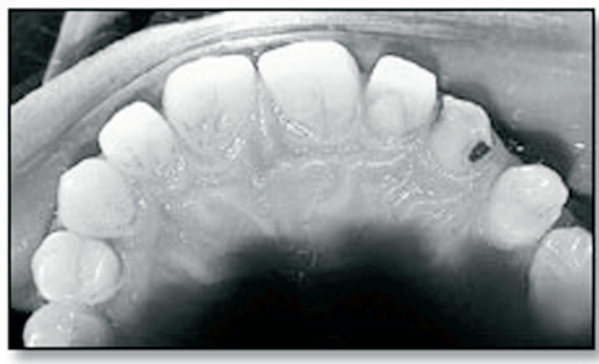

Figure 2. Intraoral view of a Type 2 talon cusp on a maxillary left lateral incisor.

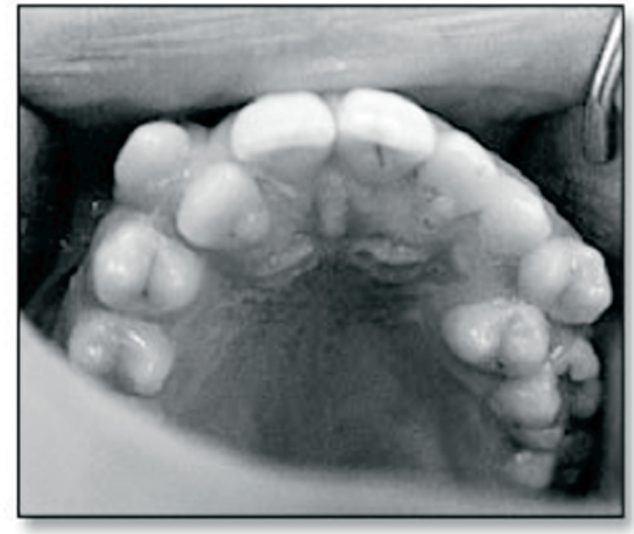

Figure 3. Intraoral view of bilateral Type 3 talon cusps on maxillary lateral incisors. 


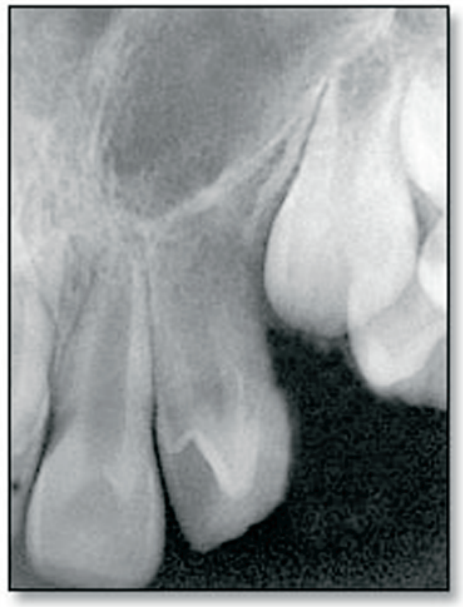

Figure 4. Periapical radiograph of Type 1 talon cusp shows V-shaped composed of enamel and dentine with pulpal extension.

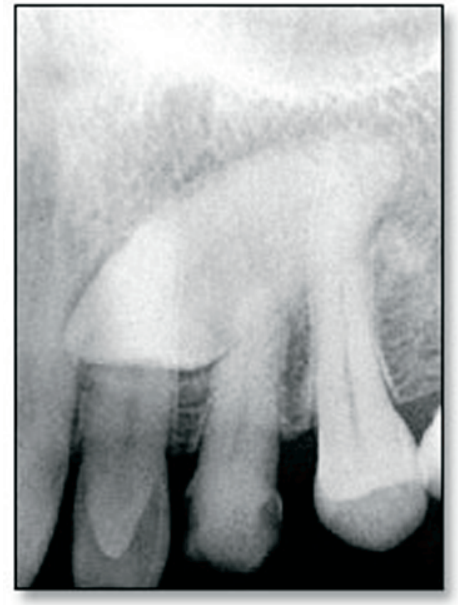

Figure 5. Periapical radiograph of Type 2 talon cusp shows V-shaped composed of enamel and dentine without pulpal extension.

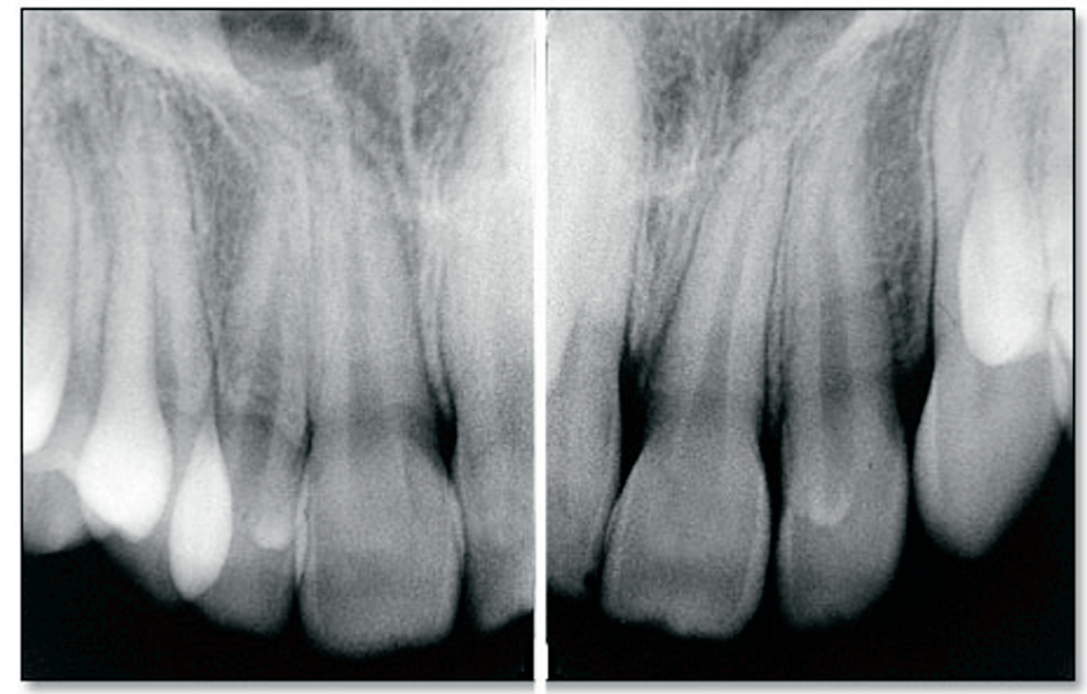

Figure 6. Periapical radiographs of Type 3 talon cusps on maxillary lateral incisor teeth.

\section{Associated Dental Anomalies and Complications}

Two of the affected teeth (6\%) were carious and required restorations while another three had very deep developmental grooves and required prophylactic treatment to prevent the development of caries. There was no sign of gingival defects caused or made worse by the groove of talon cusp as it extends subgingivally. Occlusal interference leading to attrition of the cusp with or without lingual displacement of the opposing teeth was observed in four patients (12\%). Three patients had associated dental anomalies. One patient had gemination $(3 \%)$ on the maxillary permanent incisors and two patients had mesiodens $(6 \%)$ on the maxillary region (Table 2 ).

\section{Discussion}

The talon cusp is a relatively rare odontogenic anomaly arising during the morphodifferentation phase of tooth development. The exact etiology of the talon cusp is unknown. ${ }^{1-8,11-17}$ Rantanen ${ }^{14}$ stated the condition may be a result of the hyperactivity of the anterior ends of the dental lamina. 


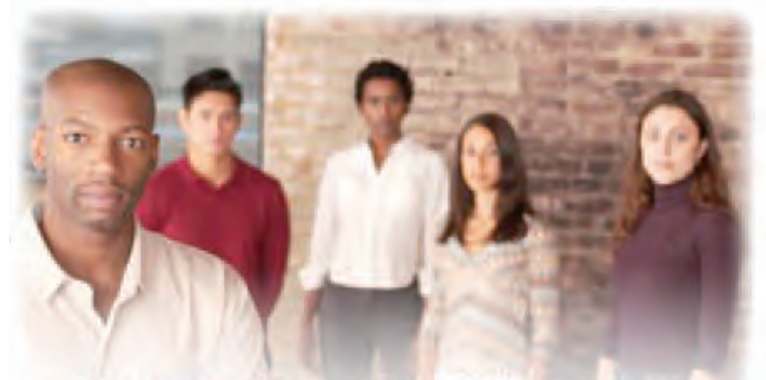

The reported prevalence of the talon cusp varies considerably between ethnic groups.

The reported prevalence of talon cusp varies considerably between ethnic groups, ranging from $0.06 \%$ in Mexican children ${ }^{9}$ to $7.7 \%$ in north Indian children. ${ }^{21}$ Males are more frequently affected than females, but the ratio was considerably higher in primary teeth $(3.5: 1)$ than in permanent teeth (1.8:1). The higher male predilection may suggest a sex-linked genetic component in the etiology of talon cusp in the primary dentition. In this study the anomaly of talon cusp was equally distributed between both sexes.

In the dental literature the talon cusp showed a striking predilection for the maxilla over the mandible. In $92 \%$ of cases the cusp was found in the maxillary anterior teeth. ${ }^{6}$ One-fifth $(20 \%)$ of the cases showed bilateral distribution of talon cusps. However, in the present study only two $(7 \%)$ out of the 27 patients had two talon cusps. All reported talon cusps in permanent teeth affected most frequently were the maxillary lateral incisor $(67 \%)$, followed by the central incisors $(24 \%)$, and canines (9\%). In the present study the talon cusp was evaluated only in the permanent dentition; maxillary lateral incisors (51\%) were most frequently involved, followed by maxillary central incisors (42\%), mandibular central incisors (3\%), and mandibular canines (3\%).

It is essential to have precise criteria for categorization of an accessory cusp such as the talon cusp. Without standardization of terminology and firm diagnostic criteria, the prevalence of the talon cusp and its clinical significance cannot be reliably estimated and evaluated. For this reason, we used the definition of talon cusp as suggested by Hattab et al. ${ }^{6}$ In the present study 33 talon cusps were examined and 15 of them were classified as Type 1 (Talon) (45\%), while eight cases were classified as Type 2 (Semi-talon)
(24\%), and ten cases were classified as Type 3 (Trace-talon) (30\%).

Several reports indicated talon cusps usually contain an extension of the pulp tissue. ${ }^{1-9,12,15}$ However, the identification of the pulpal configuration inside the talon cusp on a periapical radiograph is difficult because the cusp is superimposed over the affected tooth crown. In the opinion of Mader and Kellogg ${ }^{13}$ large talon cusps (Type 1), especially when separated from the lingual surface of the tooth, seem more likely to contain pulpal tissue. Gungor et al. ${ }^{12}$ reported the histologic presence of pulpal tissue in bilateral talon cusps of primary central incisors. In the present study 15 Type 1 talons were detected but only 12 cases had pulp extension into the cusp according to the radiological findings in the present study. Neither the Type 2 nor the Type 3 talon cusps had pulp extensions into the cusp.

There are many case reports of patients having complications with talon cusps and dental abnormalities. ${ }^{18,12-17}$ Most cases of talon cusps need definitive treatment. The developmental grooves at the lateral aspects of the anomalous cusps are susceptible to caries. Deep, noncarious grooves and fissures should be cleaned of debris and plaque and prophylactically sealed with a fissure sealant. ${ }^{6}$ If the grooves are carious, the lesion should be eradicated and the cavity filled with an appropriate restorative material. In cases of premature contact and occlusal interference the anomalous cusp should be reduced. If the treatment requires the removal of a substantial portion of the cusp, then reduction should be gradual and on consecutive visits at six to eight-week intervals to allow deposition of reparative dentin for pulpal protection. ${ }^{6,7}$ In this study the most common complication found was occlusal interference (12\%) followed by carious grooves $(6 \%)$.

Talon cusps may be associated with other dental anomalies, suggesting a genetic asoociation. ${ }^{2,6,7}$ The commonly associated anomalies include shovel-shaped lateral incisors, agenesis or impacted canines, mesiodens, complex odontomes, gemination, macrodontia, dens evaginatus of posterior teeth, peg-shaped lateral incisors, dens invaginatus, and an exaggerated Carabelli cusp., ${ }^{5,69-11}$ This could probably be explained by Rantanen's ${ }^{22}$ theory of hyperactivity 
of the anterior part of the dental lamina. Three of the 27 patients with talon cusps in the present study were observed to exhibit co-existing dental anomalies; two had mesiodens on the maxilla, while one had gemination on the maxillary central incisors.

\section{Conclusion}

The talon cusp remains as one of the more uncommon dental anomalies worldwide and in Turkey and presents with different clinical features. Its presence may or may not cause dental problems or be associated with other dental anomalies.

\section{Clinical Significance}

The talon cusp, which is a rare dental anomaly, may be more likely to be associated with other odontogenic anomalies and some systemic conditions. Early recognition of this anomaly is essential to provide proper treatment.

\section{References}

1. Mellor JK, Ripa LW. Talon cusp: a clinically significant anomaly. Oral Surg Oral Med Oral Pathol 1970; 29:225-8.

2. Mader CL. Talon cusp. J Am Dent Assoc 1981; 103:244-6.

3. Shafer WG, Hine MK, Levy BM. A textbook of oral pathology. 4th ed, pp 40 Philadelphia: WB Saunders, 1983.

4. Davies PJ, Brook AH. The presentation of talon cusp: diagnosis, clinical features, associations and possible aetiology. Br Dent J 1986; 160:84-8.

5. Al-Omari, Hattab FN, Darwazeh MG, Dummer PM. Clinical problems associated with unusal cases of talon cusp. Int Endod J 1999; 21:183-90.

6. Hattab FN, Yassin OM, Al-Nimri KS. Talon cusp in permanent dentition associated with other dental anomalies: a review of literature and reports of seven cases. J Dent Child 1996; 63:368-76.

7. Hattab FN, Yassin OM. Bilateral talon cusps on primary central incisors: a case report. Int J Paediatr Dent 1996; 6:191-5.

8. Myers CL. Treatment of a talon cusp incisor: Report of case. J Dent Child 1980; 47:119-21.

9. Sedano HO, Carreon Freyre I, Garza de la Garza ML, Gomar Franco CM, Grimaldo Hernandez C, Hernandez Montoya ME, Hipp C, Keenan KM, Martinez Bravo J, Medina López JA. Clinical orodental abnormalities in Mexican children. Oral Surg, Oral Med, Oral Pathol 1989; 68:300-11.

10. Goldstein E, Medina JJ. Mohr Syndrome or oral-facial-digital II; report of 2 cases. J Am Dent Assoc 1974; 89:377-82.

11. Gardner DG, Girgis SS. Talon cusp, a dental anomaly in the Rubenstein-Taybi syndrome. Oral Surg Oral Med Oral Path 1979; 47:519-21.

12. Güngör C, Altay N, Kaymaz F. Pulpal tissue in bilateral talon cusps of primary central incisors. Oral Pathol Oral Radiol Endod 2000; 89:231-35.

13. Mader CL, Kellogg SL. Primary talon cusp. J Dent Child 1985; 52:223-6.

14. Rantanen AV. Talon cusp. Oral Surg Oral Med Oral Pathol 1971; 32:398-400.

15. Lomçali G, Hazar S, Altınbulak H. Talon cusp: Report of five cases. Quint Int 1994; 25:431-3.

16. Hegde S, Kumar A. Mandibular talon cusp: report of two rare cases. Int J Paediatr Dent 1999; 9:303-6.

17. Oredugba F. Mandibular facial talon cusp: Case report. BMC Oral Health 2005; 5:9-14.

18. Chen RJ, Chen HS. Talon cusp in primary dentition. Oral Surg Oral Med Oral Pathol 1986; 62:67-72.

19. Tsutsumi T, Oguchi $\mathrm{H}$. Labial talon cusp in a child with incontinetia pigmenti achromians: case report. Pediatr Dent 1991; 13:236-7.

20. Hattab FN, Yassin OM, Sasa IS. Oral manifestations of Ellis-van Creveld syndrome: report of two siblings with unusual dental anomalies. J Clin Ped Dent 1998; 22:159-16.

21. Chawla HS, Tewari A, Gopalakrishnan NS. Talon cusp: a prevelance study. J Indian Soc Pedod Prevg Dent 1983; 1:28:34.

22. Rantanen AV. Talon cusp. Oral Surg Oral Med Oral Pathol 1971; 32:398-400. 
About the Authors
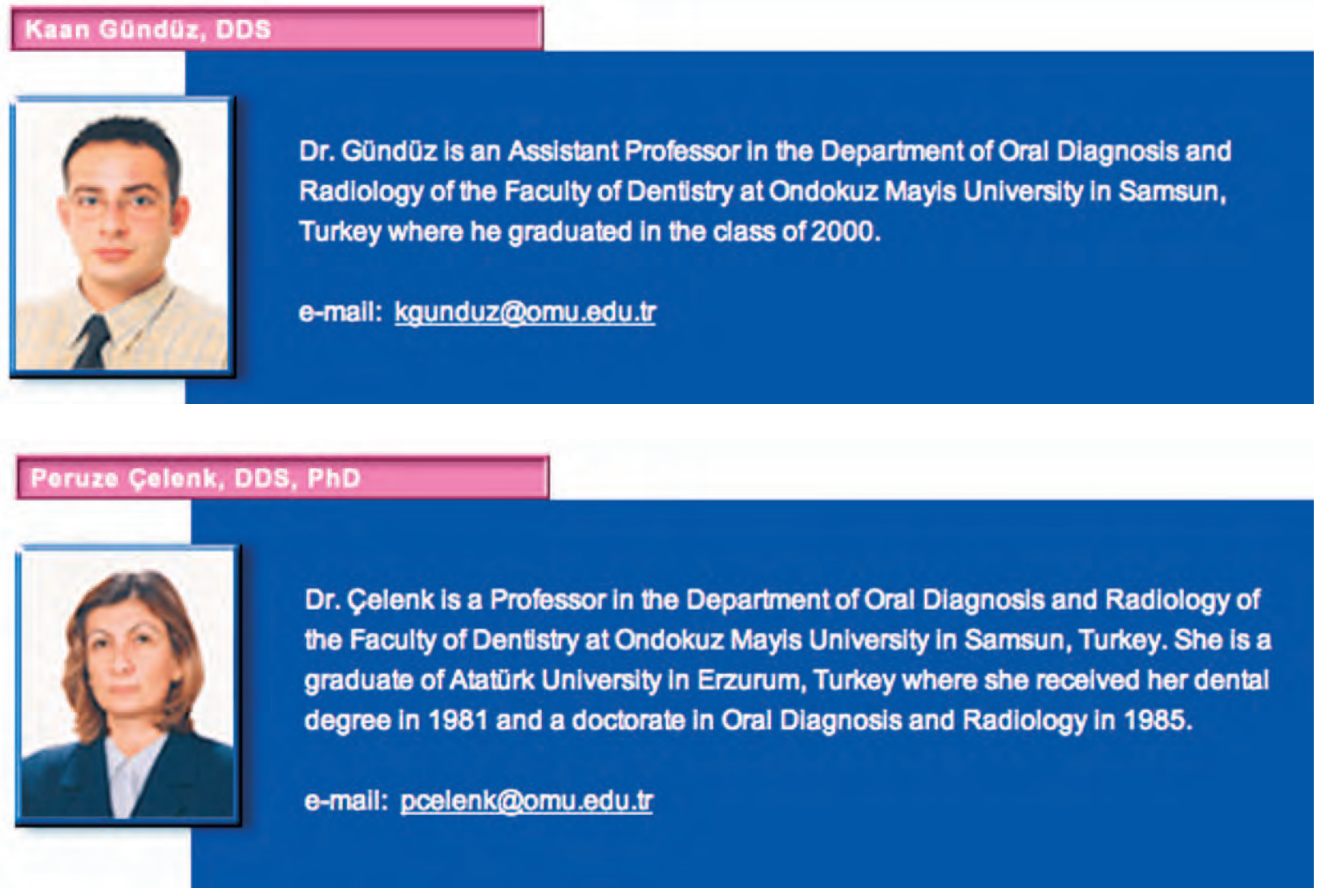